\title{
Pharmacobiological Approach for the Clinical Development of Ruxolitinib in Myeloproliferative Neoplasms
}

\section{Miyeloproliferatif Neoplazilerde Ruxolitinib İlacının Klinik Geliştirilmesine Farmakobiyolojik Yaklaşım}

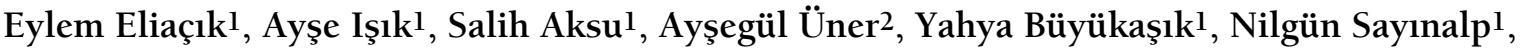
Hakan Gökerl', Osman İ. Özcebel, İbrahim C. Haznedaroğlu ${ }^{1}$

${ }^{1}$ Hacettepe University Faculty of Medicine, Department of Hematology, Ankara, Turkey

${ }^{2}$ Hacettepe University Faculty of Medicine, Department of Pathology, Ankara, Turkey

\begin{abstract}
:
Ruxolitinib, a JAK1 and JAK2 inhibitor drug, has recently been approved for the treatment of patients with high- or intermediaterisk myelofibrosis with symptomatic splenomegaly. Ruxolitinib is the first clinically useful targeted therapy in Philadelphia chromosome-negative myeloproliferative neoplasms (MPNs). The aim of this paper is to indicate pharmacobiological aspects of ruxolitinib within the potential context of MPNs. Pharmacobiological assessments, in addition to knowledge of the risk profile for ruxolitinib in MPNs, are required. We propose hypotheses based on our experience in a splenectomized MPN patient with hyperproliferative bone marrow and moderate fibrosis receiving ruxolitinib. We believe that a true clinical development approach for this drug should include pharmacobiological assessments for ruxolitinib in addition to the disease risk profile of MPNs.
\end{abstract}

Key Words: Myeloproliferative neoplasms, Ruxolitinib, Myelofibrosis

Özet:

Ruxolitinib, JAK1 ve JAK2 inhibitörü olarak işlev gören bir ilaçtır. Semptomatik splenomegalisi olan orta- veya yüksek-risk myelofibrozis hastalarında kullanımı uluslararası onam almıştır. Bu bağlamda ruxolitinib, Philadelphia kromozomu negatif myeloproliferatif neoplaziler (MPN) için klinik yararı gösterilen ilk hedefe yönelik ajan konumundadır. Bu yazının amacı, ruxolitinibin MPN'nin klinik tablolarındaki potansiyel kullanım alanları konusunda farmakobiyolojik yönleri tartışmaktır. Ruxolitinib onamları başlıca hastalık risk faktörleri üzerinden yapılmaktadır. Ancak klinik kullanımda hastalığın ve ilacın farmakobiyolojik yönlerini de dikkate alma gerekliliği vardır. Bu hipotezimizi tartışırken splenektomize bir MPN hastamızda, hiperproliferatif bir kemik iliği ve orta derecede fibrozis mevcutken uyguladığımız ruxolitinib tedavisinden elde ettiğimiz deneyimlere dayandık. İlacın gelecekte klinik geliştirilmesi gerçekleştirilirken MPN risk profili yanı sıra farmakobiyolojik değerlendirmelerin de yapılması gerektiği düşüncesindeyiz.

Anahtar Sözcükler: Myeloproliferatif neoplaziler, Ruxolitinib, Miyelofibroz

Address for Correspondence: Eylem ELİAÇIK, M.D.

Hacettepe University Faculty of Medicine, Department of Hematology, Ankara, Turkey

E-mail: eylemeli@gmail.com

Received/Gelis tarihi : July 30, 2013

Accepted/Kabul tarihi : December 30, 2013 


\section{Introduction}

Ruxolitinib, a JAK1 and JAK2 inhibitor drug, has recently been approved for the treatment of patients with high- or intermediate-risk myelofibrosis (MF) with symptomatic splenomegaly [1]. This approval in MF depends upon 2 different phase 3 randomized clinical trials (RCTs), namely COMFORT-I and COMFORT-II. COMFORT-I compared ruxolitinib with a placebo in 309 patients with MF, whereas COMFORT-II compared the drug with the best-available therapy (mostly hydroxyurea) in $219 \mathrm{MF}$ patients. Both of the RCTs attained the primary endpoint of $>35 \%$ reduction in spleen size, as measured by imaging techniques, at 24 or 48 weeks after ruxolitinib treatment initiations [2,3]. Clinical development of ruxolitinib is currently focused on the Philadelphia-negative myeloproliferative neoplastic disorders (Ph-MPNs) [4].

Ruxolitinib is a "JAK-STAT signaling pathway inhibitor" targeted drug with predictable pharmacobiological actions. The main function of the JAK-STAT signaling pathway is cellular proliferation in health and disease. Ruxolitinib should thus be considered as an "anti-proliferative" medicine $[4,5,6,7]$. Ruxolitinib has the potential to inhibit neoplastic cellular proliferation of MPNs and can cause cytopenias due to its "anti-proliferative" effects in any hematopoietic lineage. The current view of ruxolitinib in MPNs is dependent upon mainly the disease risk profile of the given MPN entity. However, this risk-only approach is not sufficient and can cause the mechanistic wrong decision that ruxolitinib is unnecessary in low-risk MPN. Likewise, ruxolitinib may be considered as ineffective, useless, harmful, or dangerous in (very) high-risk advanced/terminal MPN due to cytopenias of the drug itself. Ruxolitinib could precipitate anemia, leukopenia, and thrombocytopenia in an already pancytopenic patient with MPN. However, there are some initial clues that ruxolitinib can reverse bone marrow fibrosis in MPN if the patient population (such as cases of hyperproliferative bone marrow with splenomegaly and peripheral cytosis) is carefully selected and long-term exposure to the drug (such as 48 months) is possible [8].

The aim of this paper is to indicate pharmacobiological aspects of ruxolitinib within the potential context of MPNs. Pharmacobiological assessments, in addition to clarification of the risk profile [9] for ruxolitinib in MPNs, are required. Current clinical challenges for ruxolitinib in MPNs are summarized in Table 1. Pharmacobiological assessments and risk profiles for ruxolitinib in MPNs are depicted in Table 2.

Case Report, Methods, and Results: A Typical Myeloproliferative Neoplasms Case to Support the Hypothesis

A 64-year-old female patient with elevated blood counts was evaluated in our hematology unit. Medical history revealed systemic hypertension for 35 years and the diagnosis of polycythemia vera (PV) 20 years earlier. In 1994, the patient underwent total gastrectomy and splenectomy in order to cure gastric cancer. The JAK2V617F mutation was also detected in due course. The patient was treated by phlebotomy only until 2003, and then hydroxyurea plus phlebotomy until 2008 to control the disease. At that time, the patient had acute respiratory failure due to hyperviscosity (Plt count over 4 million per $\mathrm{mm}^{3}$ and white blood cell (WBC) count of about 50,000 per $\mathrm{mm}^{3}$ ), deep vein thrombosis, gastrointestinal bleeding, nasal bleeding, and hydroxyurea-induced skin lesions. After emergency treatment with leukapheresis and Ara-C infusions, an effort was made to control the patient's thrombocytosis with aa combination of hydroxyurea plus anagrelide. In the following years, the patient had several severe attacks due to hyperleukocytosis (WBC count reaching 120,000 per $\mathrm{mm}^{3}$ ) and extreme thrombocytosis (Plt count reaching 2 million per $\mathrm{mm}^{3}$ ) with hyperproliferative bone marrow (Figure 1) requiring intermediate doses of Ara-C infusions for 3-5 days. In June 2012, PEG-IFN treatment (180 $\mu \mathrm{g} /$ week) was initiated to control the PV. In October 2012, ruxolitinib (10 mg b.i.d.) was added to the treatment schedule and the dose of PEG-IFN was set as $90 \mu \mathrm{g}$ in this dual combination. Complete blood counts were stable and the ongoing hemostatic systemic complications due to cytosis were successfully controlled with this combination treatment (Figure 2).

Our patient represents a model of the ideal MPN population in which ruxolitinib should be administered, with hyperproliferative bone marrow with or without fibrosis and peripheral cytosis and organomegaly. Informed consent was obtained.

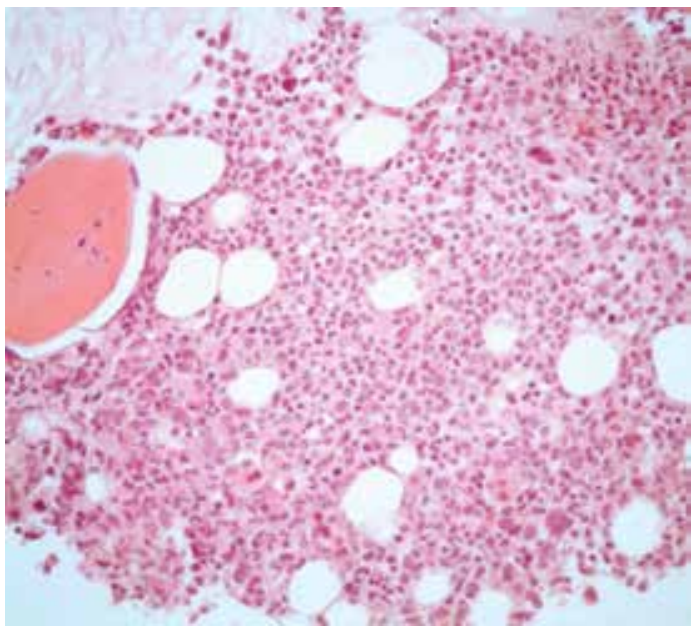

Figure 1. Hyperproliferative bone marrow of the patient diagnosed with JAK2V617F-positive polycythemia vera. Hypercellular bone marrow with grade 1 fibrosis and trilineage hyperplasia (100x). 


\section{Discussion}

Patients who have hyperproliferative bone marrow in any lineage (enhanced granulopoiesis, erythropoiesis, thrombopoiesis) plus/minus fibrosis with or without peripheral cytosis (hyperleukocytosis, polycythemia, thrombocytosis), and splenomegaly plus peripheral cytosis (hyperleukocytosis, polycythemia, thrombocytosis); all of the ruxolitinib arm of the RESPONSE trial patients; all ruxolitinib-

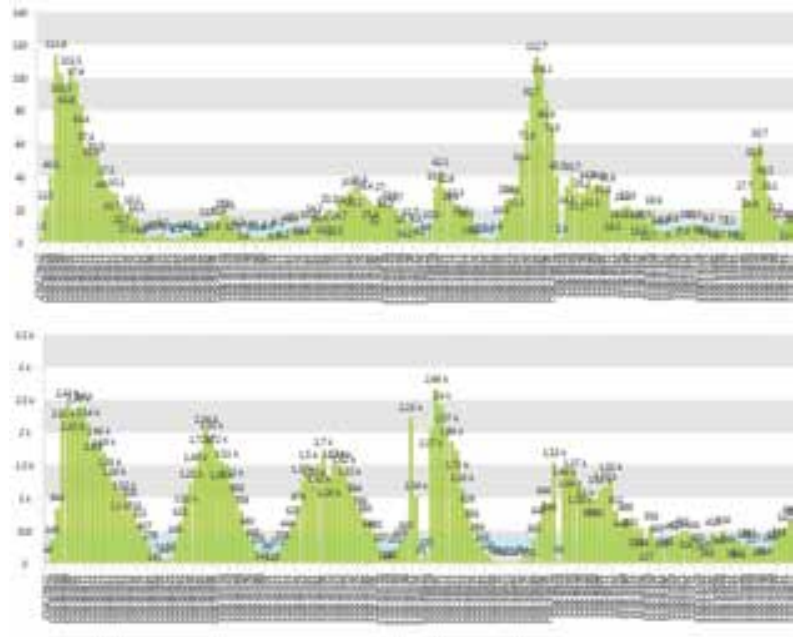

Figure 2. Peripheral white blood cell (upper panel) and Plt (lower panel) counts of the patient diagnosed with JAK2V617F-positive polycythemia vera. Control of the neoplastic cellular proliferation was obtained via a PEGintron + ruxolitinib combination. receiving prefibrotic primary myelofibrosis (PMF, WHO 2008) patients; all ruxolitinib-receiving patients splenectomized for any reason; and any MPN patient to whom ruxolitinib was already administered within other trials (COMFORT-I, COMFORT-II, and others) on compassionate use could be registered and independently evaluated in the context of a 'Ruxolitinib Pan-MPN Trial'. In this specific MPN patient population (Ruxolitinib Pan-MPN Registry), some critical clinical/laboratory evaluations including effects of ruxolitinib on white blood cell counts (control versus leukopenia) and leukostasis/infections, on hematocrit levels (control versus anemia) and hyperviscosity, on platelet levels (control versus thrombocytopenia) and leukostasis/thrombosis/ hemorrhage, on hepatic enlargement and complications of portal hypertension (particularly after splenectomy), and on hyperproliferative bone marrow neoplastic cellular proliferation and fibrosis would be assessed. MPN disease risk categories of this specific MPN patient population should be detected, as well as the established clinically important ruxolitinib effects (reduction in spleen size and MPN symptoms).

A Ruxolitinib Pan-MPN Phase II study should be performed if the Step 1 Ruxolitinib Pan-MPN Registry reveals that ruxolitinib can control hyperproliferative bone marrow (enhanced granulopoiesis, erythropoiesis, thrombopoiesis), fibrosis and/or peripheral cytosis (hyperleukocytosis, polycythemia, thrombocytosis), cytosis-related acute/sub-acute complications (hyperleukocytosis, polycythemia, thrombocytosis), or hepatic enlargement and complications of portal hypertension (particularly after splenectomy), or can decrease spleen size in $\mathrm{PV}$ and normalize bone marrow architecture in MPNs in the long

Table 1. Current clinical challenges for ruxolitinib in myeloproliferative neoplasms (MPNs).

\section{(Very) Low-Risk MPN}

Survival is long and may not even differ from that of the healthy population in some low-risk MPNs like ET and PV.

Competitors of ruxolitinib are observation only, low-dose aspirin, phlebotomy, hydroxyurea, and anagrelide. All of them are cheaper and safer in most cases.

There are no data that long-term ruxolitinib may affect disease course via the prevention of bone marrow fibrosis in low-risk MPN.

\section{(Very) High-Risk MPN}

Profound deep (pan) cytopenias already extant in high-risk MPN could become worse after the addition of ruxolitinibinduced cytopenias.

Inability to administer ruxolitinib at optimal dosage and duration due to cytopenias in high-risk MPN. Interruption and discontinuation of the drug (ruxolitinib cessation syndrome).

Ruxolitinib may not improve already very shortened survival, morbidity, and comorbidities due to advanced/terminal MPNs.

Ruxolitinib may not improve irreversible severe organ damage due to advanced/terminal MPN (hepatic failure, portal hypertension bone marrow failure, huge spleen, etc.). 
Table 2. The need for pharmacobiological assessments in addition to the risk profile for ruxolitinib in myeloproliferative neoplasms (MPNs).

\begin{tabular}{|c|c|c|}
\hline $\begin{array}{l}\text { Current concerns regarding } \\
\text { ruxolitinib }\end{array}$ & $\begin{array}{l}\text { Ideal MPN subpopulation for rux- } \\
\text { olitinib administration }\end{array}$ & $\begin{array}{l}\text { Expected outcome in the given } \\
\text { population based on pharmaco- } \\
\text { biology }\end{array}$ \\
\hline $\begin{array}{l}\text { Ideal MPN subpopulation for } \\
\text { ruxolitinib administration. }\end{array}$ & $\begin{array}{l}\text { Increased bone marrow erythropoiesis } \\
\text { (and/or peripheral erythrocytosis). }\end{array}$ & $\begin{array}{l}\text { Suppression of neoplastic erythropoiesis } \\
\text { (with } \mathrm{Hb} \text { control). }\end{array}$ \\
\hline $\begin{array}{l}\text { Causing drug-induced leukopenia } \\
\text { in an already leukopenic MPN } \\
\text { patient. }\end{array}$ & $\begin{array}{l}\text { Increased bone marrow granulopoiesis } \\
\text { (and/or peripheral leukocytosis). }\end{array}$ & $\begin{array}{l}\text { Suppression of neoplastic granulopoiesis } \\
\text { (with WBC control). }\end{array}$ \\
\hline $\begin{array}{l}\text { Causing drug-induced } \\
\text { thrombocytopenia in an already } \\
\text { thrombocytopenic MPN patient. }\end{array}$ & $\begin{array}{l}\text { Increased bone marrow thrombopoiesis } \\
\text { (and/or peripheral thrombocytosis). }\end{array}$ & $\begin{array}{l}\text { Suppression of neoplastic } \\
\text { megakaryocyto-thrombopoiesis (with Plt } \\
\text { control). }\end{array}$ \\
\hline $\begin{array}{l}\text { Ruxolitinib-withdrawal syndrome } \\
\text { due to discontinuation. }\end{array}$ & $\begin{array}{l}\text { Expected outcome in the given population } \\
\text { based on pharmacobiology. }\end{array}$ & $\begin{array}{l}\text { Expected outcome in the given } \\
\text { population based on pharmacobiology. }\end{array}$ \\
\hline $\begin{array}{l}\text { Decreasing spleen size without } \\
\text { clinical improvement. }\end{array}$ & $\begin{array}{l}\text { Expected outcome in the given population } \\
\text { based on pharmacobiology. }\end{array}$ & $\begin{array}{l}\text { Controlling the neoplastic cellular } \\
\text { growth preventing the acute cytosis } \\
\text { complications/symptoms and reducing } \\
\text { spleen size. }\end{array}$ \\
\hline $\begin{array}{l}\text { Failure to control hepatic } \\
\text { extramedullary hematopoiesis. }\end{array}$ & $\begin{array}{l}\text { Already splenectomized MPN patient for } \\
\text { any reason and peripheral cytosis. }\end{array}$ & $\begin{array}{l}\text { Controlling the complications of portal } \\
\text { hypertension with the inhibition of } \\
\text { hepatic extramedullary hematopoiesis. }\end{array}$ \\
\hline $\begin{array}{l}\text { Failure to modify MPN bone } \\
\text { marrow architecture. }\end{array}$ & $\begin{array}{l}\text { Controlling the complications of portal } \\
\text { hypertension with the inhibition of } \\
\text { hepatic extramedullary hematopoiesis. }\end{array}$ & $\begin{array}{l}\text { Reversal and/or prevention of } \\
\text { progression in BM fibrosis. }\end{array}$ \\
\hline
\end{tabular}

MPN: myeloproliferative neoplasms, WBC: white blood cell.

term in a study population whose main inclusion criteria are any MPN patient with hyperproliferative bone marrow in any lineage AND bone marrow fibrosis AND splenomegaly AND peripheral cytosis in at least one lineage (hyperleukocytosis, polycythemia, thrombocytosis), and all of the MPN patients with PMF (WHO 2008). These proposals will be tested as hypotheses on efficacy. Hypotheses on safety, including that the degree of ruxolitinibinduced anemia, leukopenia, thrombocytopenia, and related complications is lower in hyperproliferative MPN and that the tolerability and adherence of ruxolitinib with proper dosage and duration is enhanced in patients with hyperproliferative MPNs, will also be tested.
The development of any drug from bench side to clinic is very difficult and expensive. Therefore, proper scientific strategy is absolutely necessary during the design of clinical studies. Ruxolitinib is the first clinically useful targeted therapy in $\mathrm{Ph}$ -MPNs. We think that a true clinical development approach for this drug should include pharmacobiological assessments for ruxolitinib in addition to the disease risk profile of MPNs.

\section{Conflict of Interest Statement}

The authors of this paper have no conflicts of interest, including specific financial interests, relationships, and/or affiliations relevant to the subject matter or materials included. 


\section{References}

1. Cervantes F, Martinez-Trillos A. Myelofibrosis: an update on current pharmacotherapy and future directions. Expert Opin Pharmacother 2013;14:873-884.

2. Harrison C, Kiladjian JJ, Al-Ali HK, Gisslinger H, Waltzman R, Stalbovskaya V, McQuitty M, Hunter DS, Levy R, Knoops L, Cervantes F, Vannucchi AM, Barbui T, Barosi G. JAK inhibition with ruxolitinib versus best available therapy for myelofibrosis. N Engl J Med 2012;366:787-798.

3. Harrison CN, Mesa RA, Kiladjian JJ, Al-Ali HK, Gisslinger H, Knoops L, Squier M, Sirulnik A, Mendelson E, Zhou X, CopleyMerriman C, Hunter DS, Levy RS, Cervantes F, Passamonti F, Barbui T, Barosi G, Vannucchi AM. Health-related quality of life and symptoms in patients with myelofibrosis treated with ruxolitinib versus best available therapy. Br J Haematol 2013;162:229-239.

4. Haznedaroglu IC. Ruxolitinib for myelofibrosis. N Engl J Med 2012;366:2032.
5. Pardanani A, Vannucchi AM, Passamonti F, Cervantes F, Barbui T, Tefferi A. JAK inhibitor therapy for myelofibrosis: critical assessment of value and limitations. Leukemia 2011;25:218-225.

6. Tefferi A, Litzow MR, Pardanani A. Long-term outcome of treatment with ruxolitinib in myelofibrosis. N Engl J Med 2011;365:1455-1457.

7. Tefferi A, Pardanani A. Serious adverse events during ruxolitinib treatment discontinuation in patients with myelofibrosis. Mayo Clin Proc 2011;86:1188-1191.

8. Kvasnicka HM, Thiele J, Bueso-Ramos CE, Hou K, Cortes JE, Kantarjian HM, Verstovsek S. Exploratory analysis of the effect of ruxolitinib on bone marrow morphology in patients with myelofibrosis. J Clin Oncol (ASCO Meeting Abstracts) 2013;31:7030.

9. Haznedaroglu IC. The therapeutic goals of essential thrombocythemia under the clouds of over-treatment and undertreatment. Expert Opin Pharmacother 2013;14:1431-1436. 